\title{
Determining Adventure Tourist Loyalty: Mediating Role of Tourist Satisfaction and Quality of Life
}

\author{
Fatchur ROHMAN ${ }^{1}$
}

Received: July 25, 2020 Revised: August 23, 2020 Accepted: August 29, 2020

\begin{abstract}
This study aims to test the interrelationship among perceived value, tourist satisfaction, quality of life, and tourist loyalty in an Indonesian tourist adventure destination. The respondents were recruited from Bromo Mountain, East-Java Province, Indonesia. For this study, 250 questionnaires were distributed, of which 240 could be used for analysis, yielding a response rate of 96\%. Data was analyzed using Partial Least Squares with smartPLS 3 software. Both outer model and inner model evaluation were conducted to ensure the robustness of the proposed model. The findings showed that perceived value does not have a direct significant effect on tourist loyalty. However, tourist satisfaction and quality of life have significant effects on tourist loyalty. The mediating effect test indicated that tourist satisfaction and quality of life significantly mediated the effect of perceived value on tourist loyalty. The multi-group analysis test found that the demographic factor does not have any influence. By accomplishing its research objectives, this study provides both theoretical and practical contributions. From a theoretical standpoint, this study provides a comprehensive conceptual model in explaining Indonesia adventure tourist loyalty. From a practical standpoint, this study offers recommendations to adventure tourism management to enhance the sustainability of the tourism destination, especially the adventure tourism destination.
\end{abstract}

Keywords: Perceived Value, Tourist Satisfaction, Quality of Life, Tourist Loyalty, Adventure Tourism

JEL Classification Code: M31, N30, Z3, Z32, Z33

\section{Introduction}

Cohen (2014) points out that consumer behavior is the subject most debated in marketing and tourism studies, where consumer behavior is best defined as travel behavior or tourism behavior. Tourism behavior research encompasses many key concepts explored by researchers to decide how tourism behavior is shaped on selected tourism items. It is important to consider key concepts in tourism behavior, as the type and form of tourism offered can affect decisionmaking and tourism activities (Cohen, 2014).

Adventure tourism is the fastest-growing tourism subsector based, as per the 2015 Adventure Travel Trade

${ }^{1}$ First Author and Corresponding Author. Management Department, Faculty of Economics and Business, Universitas Brawijaya, Indonesia [Postal Address: Jl. MT, Haryono 165, Malang, Jawa Timur, 65142, Indonesia] Email: fatchur@ub.ac.id

(c) Copyright: The Author(s)

This is an Open Access article distributed under the terms of the Creative Commons Attribution This is an Open Access article distributed under the terms of the Creative Commons Attribution
Non-Commercial License (https://creativecommons.org/licenses/by-nc/4.0/) which permits unrestricted non-commercial use, distribution, and reproduction in any medium, provided the original work is properly cited.
Association record. Chandel and Bansal (2014) argue that rapid growth in the adventure tourism subsector is supported by the high income generated by the subsector compared to other subsectors. Tourists in the adventure tourism subsector, not only spend money to go to and enjoy tourism destinations, but also incur costs to buy equipment needed to enjoy these tourist destinations. Hudson (2012) clarified the two types of adventure tourism subsector: hard and soft adventure. A hard adventure is described as an adventure tour requiring high physical ability, triggering high adrenaline. In this category, tourists need complete equipment, and may face a high risk from activities at tourist destinations. Soft adventure is described as an adventure tour that offers exploration activities or activities that are virtually risk-free. Tourists traveling with family or age groups who don't want to take extreme risks found in the hard adventure category often choose the soft adventure category.

Buckley (2010) explained that adventure tourism has two characteristics that can distinguish this tourism subsector compared to other subsectors. Adventure tourism always related to nature as a location where various forms of attractions offered by tour managers can be enjoyed, and adventure tourism always presents a risk to tourists. William 
and Soutar (2009) explained that perceived value is one of the most important concepts in observing tourist behavior in the adventure tourism subsector. Risks that are part of adventure tourism could affect how tourists perceived the value of a destination site.

Giddy and Webb (2018) explain that there is a link between adventure tourism, the environment, and the sustainability of the destination site. Previous studies found that adventure tourism has a significant influence on the environment (Cole, 2004; Leung \& Marion, 2004; Lucrezi et al., 2013). Activities such as mountain climbing, horse riding, or water sports indirectly affect the ecosystem found on tourism sites. Indonesia scored very low in the ability to manage the sustainability of its tourism resources (World Economic Forum 2019). In 2019, the country achieved 3.5 out of 7 scale on its ability to manage the sustainability of its tourism resources. This is a very disappointing result considering the number of available tourism resources in the country.

Brymer and Gray (2010) report that high participation in hard adventure activities can increase tourists' appreciation of the environment. This report supports previous studies (Brymer, et al. 2009; Schultz, 2000) that found that high tourist participation in nature and the environment can improve the love of for the environment, which is expected to increase tourist awareness to help maintain the sustainability of tourist sites. Pomfret and Bramwell (2014) also explained that the level of tourists' participation could also influence their perceived value toward the destinations they visited. Perceived value is considered as one of the factors that can influence tourist satisfaction and loyalty (William \& Soutar, 2009; Chandel \& Bansal, 2014; Chandel et al., 2018). Based on this paradigm, we believe perceived value, not only has a vital role in influencing tourist behavior, but also has the potential to help improve the sustainability of tourist sites through increasing tourist awareness to care for the environment of these destinations.

While previous studies have mentioned the relationship between perceived value and tourist loyalty, there is still a gap in the literature. The results of previous studies indicate that there are inconsistent results as regards the relationship between the two variables. A positive and significant effect of perceived value on tourism loyalty can be found in Chen and Chen (2010); May-Lien (2011); Pandža Bajs (2015), but Jin et al. (2013) found no significant impact on this relationship. To fill this gap, this study inserted the idea of tourist satisfaction and tourist quality of life as the mediating variables. Tourist satisfaction is inserted as a mediating variable since previous studies showed that tourist satisfaction is the result of perceived value, and it is the determinant of tourist loyalty. Similar to tourist satisfaction, previous studies have explained the important role of perceived value in creating quality of life. Moreover, the effect of quality of life on tourist loyalty was found. Besides integrating tourist satisfaction and quality of life as mediating variables, this study integrates demographics as the moderating variable since previous studies say that behavior-related demographics varies (Pomfret \& Bramwell, 2014).

Based on this background, this study aims to: 1) investigate the relationship among perceived value, tourist satisfaction, quality of life, and tourist loyalty in the context of Indonesia tourist adventure; 2) determine the mediating effects of tourist satisfaction in the relationship between perceived value and tourist loyalty; and 3) test the moderating effect of demographics. Upon achieving these research objectives, this study contributes to both theoretical and practical perspectives. From a theoretical point of view, this study builds a comprehensive model that integrates perceived value, tourist satisfaction, quality of life, and demographics to explain adventure tourism loyalty. From a practical contribution, this study provides a guideline for adventure tourist practitioners in enhancing tourism adventure loyalty.

\section{Literature Review}

\subsection{Tourist Behavior Model}

Tourist behavior is a concept used to describe the decision-making process up to the activities carried out by tourists in consuming products offered by a tourist destination. The process of tourist behavior includes the same stages compared to the process of consumer behavior, which starts with product selection, decision-making, and finally consuming the selected product. Cohen (2014) argues that the model of consumer behavior is the topic most often used in marketing research especially in tourism, but the direct adaptation of the consumer behavior model to describe tourist behavior has several limitations.

Cohen (2014) explained that one limitation in the adaptation of consumer behavior models to research in tourism is that there is a similar variable relationship, but these results cannot be declared valid because of differences in the characteristics of the tourists or tourist destinations they visit. For example, the perceived value of adventure destinations could have different measurements if research is conducted on tourists visiting spiritual tourism destinations. Based on these examples, the adaptation of the consumer behavior model needs to be adjusted to the characteristics of the object being observed or the context used in the study.

Nine key concepts could be observed in tourist behavior research when building a comprehensive model that is expected to describe the process of behavior formation in tourists (Cohen, 2014). The nine concepts include decisionmaking, values, motivation, self-concept and personality, 
expectations, attitudes, perceptions, satisfaction, and trust and loyalty. In this study, a comprehensive model of tourist behavior is constructed using several key concepts. Perceived value is formed from the concepts of values, expectations, and perceptions. Satisfaction and tourist loyalty are formed from the concepts of satisfaction, trust, and loyalty. Finally, the quality of life variable is formed from self-concept and personality.

Pomfret and Bramwell (2014) argue that demographic factors such as age and gender could influence models of tourist behavior, especially in the field of adventure tourism. Age is considered to influence the motivation to do adventure activities (Cater, 2006; Patterson \& Pan, 2007; Boyes, 2013). Bialeschki and Henderson (2000) found that male tourists have a higher motivation to undertake harder adventure activities than female tourists. Results of these previous studies lead us to add several demographic factors such as age, gender, marital status, and area of origin into a comprehensive model designed to clarify descriptions of tourist behavior in adventure tourism

\subsection{Tourist Perceived Value}

Sweeney et al. (1999) give a simple definition of value as a comparison between benefits and costs. The conceptual framework of the perceived value formed by Sweeney and Soutar (2001) is used to measure how a consumer perceives the value of a product. Measurement of perceived value has four indicators, including functional value, value to cost, social value, and emotional value. Functional value is an indicator that measures the physical functionality of a product. Quality, reliability, durability, and price are attributes commonly found in functional value (Williams \& Soutar, 2009; Chandel \& Bansal, 2014). The value of costs is a measurement of the costs needed to consume a product. The value of the costs would increase if the benefits derived from using the product can exceed the expectations of consumers.

Emotional value is described as the ability of the product to produce feelings of pleasure or happiness when or after consumption (Sheth et al. 1991). Social value is described as the value that can be formed by social interaction or recognition obtained after consuming a product. Willams and Soutar (2009) explained in the context of tourism that social value is formed through interaction between tourist participants in a tourist destination or recognition of the social environment after a tourist visit. Perceived value is an important variable in the tourist behavior model. Perceived value is found to influence tourist loyalty (Chen \& Chen, 2010; Li, 2011; Pandža Bajs, 2015). Perceived value is also found to have a significant effect on tourist satisfaction (Williams \& Soutar; 2009; Chandel, 2014; Chandel et al., 2018).

\subsection{Tourist Satisfaction}

In most consumer behavior model, satisfaction is in a central position between the descendants and antecedents variables. Correia et al. (2009) describe satisfaction as a comparison between expectations and performance of a product. The performance of a product is indicated by the benefits produced by the product when consumed; if the benefits produced meet or exceed the expectations of consumers, the customer would be satisfied. Homburg et al. (2005) measure satisfaction through evaluating the experience of consuming products by consumers. Various models of consumer behavior have confirmed the effect of satisfaction on tourist loyalty (Zabkar et al., 2010; Prayag et al., 2013; Ismail et al., 2016).

\subsection{Quality of Life}

Quality of life is described as a condition showed by someone when living a good quality life (Ventegodt et al., 2003). A person's motivation to live a good quality of life has become a topic of research, especially in the field of marketing in the last few decades (Carneiro \& Eusabio, 2011). These studies find that the quality of life produced in the process of consuming a product in the form of goods or services influences customer satisfaction and loyalty.

Bonsjak et al. (2011) developed a model to measure the quality of life that can be formed by tourists when visiting a tourist destination. In this model, seven criteria could be formed by tourist destinations to produce the quality of life for tourists. These criteria include self-congruence, functional congruence, comfort congruence, health and safety, moral congruence, economic congruence, and hedonic aspects. Neal et al. (2007) argue that quality of life and satisfaction have a close enough relationship that needs to be observed in a comprehensive model.

\subsection{Tourist Loyalty}

Kim et al. (2011) explained that consumer behavior in repurchasing a product is strongly influenced by high trust in a product. Trust grows in consumers along with meeting consumer expectations from time to time. Oliver (1997) explained that loyalty is a form of consumer behavior that shows a commitment to repurchase a product and refuse to buy products with other brands or produced by different manufacturers. In general, the measurement of consumer loyalty consists of three indicators, including behavior, attitude, and composite (Opperman, 2000). Previous studies have found some antecedents of tourist loyalty, but there are only a few variables that have consistency in determining loyal tourist behavior. Perceived value and customer satisfaction are two variables that are found in almost 
tourist behavior models and have a significant influence on determining tourist loyalty.

\subsection{Hypothesis and Model Development}

Perceived value has been recognized widely as the important construct in the realm of marketing. Previous studies have suggested its essential role in generating customer loyalty. In the area of tourism and hospitality studies, Channoi et al. (2018) found a significant positive effect of perceived value of tourist loyalty in visiting beach resort hotels in Thailand. Similar to this study, Hapsari (2018) showed that perceived value plays an important role in affecting visitor loyalty of educational theme park in Indonesia. The effect of perceived value on behavioral intention in the perspective of tourism study was also revealed by El-Adly (2019) in the context of UAE hotel customers. Tran (2020) claimed that perceived value has a significant positive effect on visitor loyalty among Vietnam tourists. Apart from its effect on customer loyalty, perceived value was found to be the determinant of quality of life. The study by Ma et al. (2018) suggested that as part of individual's attitude, perceived value significantly affect individual's subjective well-being in riding bicycle. The effect of perceived value on quality of life was also found by Berutu et al. (2020) in the context of Indonesia tourism destination. As the determinants of both loyalty and quality of life, perceived value is predicted to have a significant positive effect on tourist satisfaction. Previous studies on the tourism sector indicated that the higher the value perceived by tourist, the higher the satisfaction of the tourist (Channoi et al., 2018; Hapsari et al., 2017; Hussein $\&$ Hapsari, 2020). Based on these studies, three hypotheses are proposed:

H1: Perceived value has a significant positive effect on tourist loyalty

H2: Perceived value has a significant positive effect on quality of life

H3: Perceived value has a significant positive effect on tourist satisfaction

Borrowing the idea of customer satisfaction, the construct of tourist satisfaction has been recognized widely as an important construct in the tourism domain. Chen et al. (2016) suggested that Chinese tourist subjective well-being was significantly affected by their satisfaction toward the destination. Similar to this study, Berutu et al. (2020) found the essential role of satisfaction in creating Indonesian tourist quality of life. Beside its effect on quality of life, tourist satisfaction has also been acknowledged as the determinant of tourist loyalty. Previous studies have recognized the important of satisfaction in generating loyalty in the area of tourism sector (Hapsari, 2018; Le \& Le, 2020; Nguyen, 2020; Wu et al., 2014). Thus, the following hypotheses are proposed:

H4: Tourist satisfaction has a significant positive effect on quality of life

H5: Tourist satisfaction has a significant positive effect on tourist loyalty

In marketing literature, subjective well-being or individual quality of life has been found to be the determinant of customer loyalty. Hernandez-Mogollon et al. (2020) contended that tourist quality of life played an important role in creating loyalty in Spain culinary tourism sector. Similar to this study, Chen et al. (2016) suggested the significant effect of quality of life on China tourist loyalty. Thus, the following hypothesis is proposed:

H6: Quality of life has a significant positive effect on tourist loyalty

As this study suggested that perceived value has a significant positive effect on quality of life (Berutu et al., 2020; Ma et al., 2018) and the quality of life is the predictor of tourist loyalty (Hernandez-Mogollon et al., 2020) there is a possibility that quality of life will mediate the effect of perceived value on tourist loyalty. Furthermore, this study suggested the important effect of perceived value of tourist satisfaction (Channoi et al., 2018; Hapsari et al., 2017; Hussein \& Hapsari, 2020), whereas tourist satisfaction was suggested as the predictor of tourist loyalty (Hapsari, 2018; Le \& Le, 2020; Nguyen, 2020; Wu et al., 2014). Parallel to quality of life, there is a possibility that tourist satisfaction will mediate the effect of perceived value on tourist loyalty. Thus, the following hypotheses are proposed:

H7: Quality of life mediates the effect of perceived value on tourist loyalty

H8: Tourist satisfaction mediates the effect of perceived value on tourist loyalty

In marketing studies, customer's demographics such as gender, marital status and customer origin have a significant effect on individual behavior. For that reason, this study proposed the following hypotheses:

H9: Demography moderates the effect of perceived value on tourist loyalty

H10: Demography moderates the effect of tourist satisfaction on tourist loyalty

H11: Demography moderates the effect of quality of life in tourist loyalty 


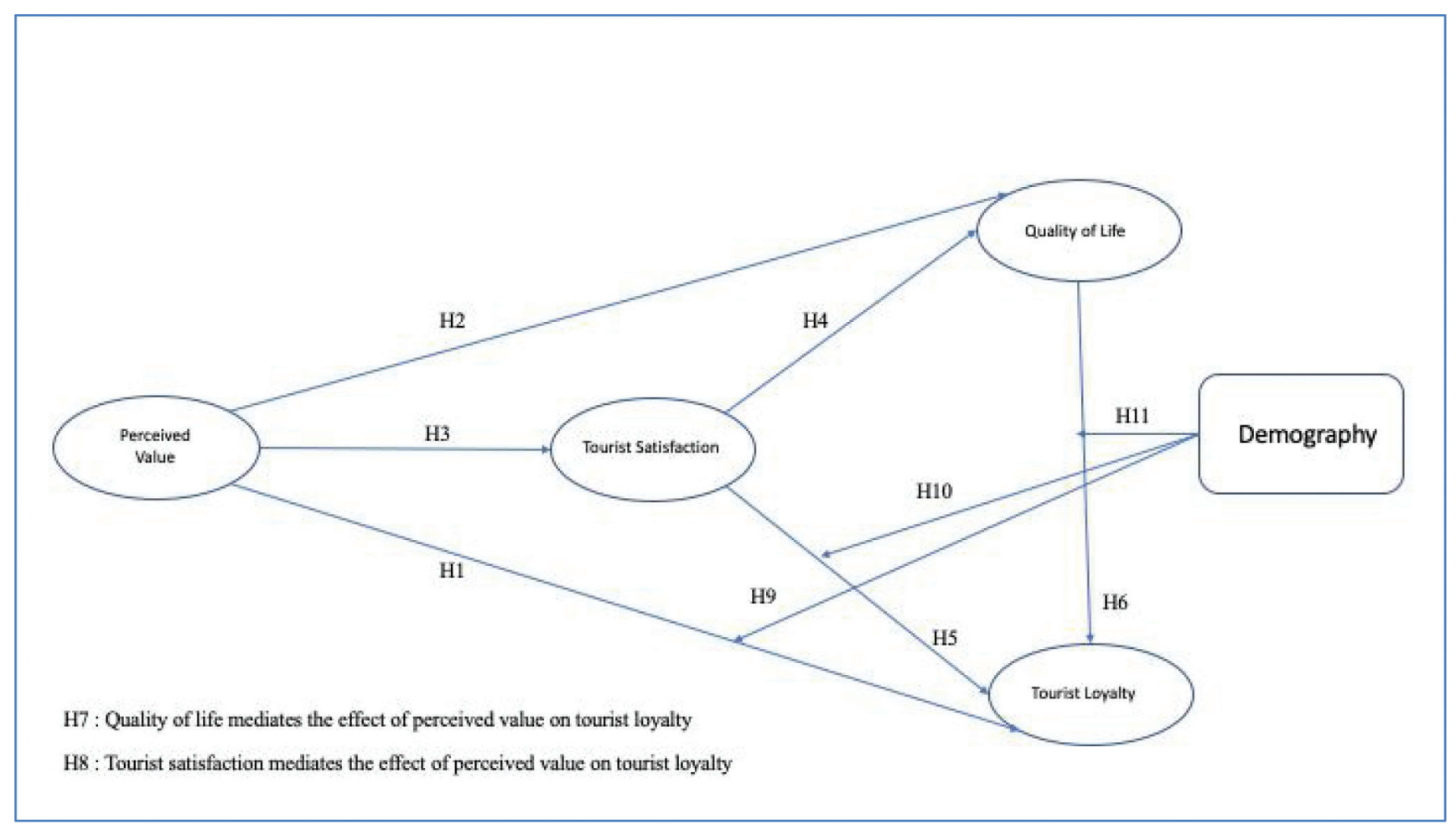

Figure 1: Conceptual Model

Figure 1 depicted the conceptual model constructed in this study.

\section{Research Methods and Materials}

\subsection{Sample}

Two hundred and fifty self-administered questionnaires were distributed to collect the data. However, only 240 questionnaires were usable for this study, yielding a response rate of $96 \%$. Accidental sampling method was used to recruit sample at Bromo Mountain, East-Java Province, Indonesia. Among the 240 respondents, 63\% were aged between 21 and $30,74 \%$ came from East-Java Province, 54\% were female, $41 \%$ were university students, and $87 \%$ were single.

\subsection{Measures}

The questionnaires used in this study was divided in two sections. The first section asked about the demographics of respondents and the second section asked about the variables used in this study. A 5-point Likert scale was used - (1) strongly disagree to (5) strongly agree. The items were adapted from several studies. Perceived value was adapted from Sweeney and Soutar (2001), tourist satisfaction was adapted from Rasoolimanesh et al. (2016), quality of life was adapted from Eusobio et al. (2016) and tourist loyalty was adapted from Hussein et al. (2018).

\subsection{Data Analysis}

Data was analyzed using Partial Least Squares (PLS) with smartPLS 3.2. Three-step analysis were performed to process the data. The first analysis is outer model evaluation. For outer model evaluation, the measures used in this study were evaluated through some indicators, namely, convergent validity, discriminant validity, and unidimensionality (Hair et al., 2014). The second step is inner model evaluation, which is indicated by coefficient of determination, predictive relevance, and Goodness of Fit Index (Esposito et al., 2010). The mediating effect was tested by using Baron and Kenny (1986) mediation test and the hypotheses were tested by using Sobel's Test.

\section{Results and Discussion}

\subsection{Outer Model Evaluation}

Outer mode evaluation aims to evaluate the measures used in this study. Three indicators were used to evaluate the measures, namely, convergent validity, discriminant validity, and unidimensionality. Convergent validity was reflected 
through the score of Average of Variance Extracted (AVE) and outer loading. To be free from convergent validity problems, the score of AVE must be above 0.5 and outer loading must be more than 0.4 (Hair et al., 2014). For this study, the initial evaluation indicated that the AVE of Quality of Life was below 0.5. To increase the AVE, the item QoL4, QoL6, QoL8 and QoL9 were removed from the model. By removing these items, the score AVE for all constructs are above 0.5 .

Discriminant validity was evaluated through evaluating the score of Heterotrait-Monotrait (HTMT). To be free from discriminant validity, the HTMT score between construct must be below 0.9(Hair et al., 2014). The estimation indicated that the measures are free from discriminant validity problem since the score of HTMT among constructs varies between 0.677 and 0.894 .

Composite reliability aims to ensure that all proposed construct are uni-dimensions. (Esposito Vinzi et al., 2010) explained that to be uni-dimension, the score of composite reliability must be larger than 0.7 . In this study, the score of composite reliability varied between 0.854 and 0.918 . This finding means that all variables are uni-dimension. Based on these three indicators, it can be concluded that the measures used are valid and reliable. Table 1 summarizes the results of outer model evaluation.

\subsection{Inner Model Evaluation}

Upon evaluation the measures used, the further analysis is to evaluate the robustness of structural model. For this study, inner model evaluation was assessed through three indicators, namely, coefficient determination (R2), predictive relevance (Q2), and Goodness of Fit (GoF). The following section will discuss the results of inner model evaluation.

Since PLS aims to predict the causality among constructs, there is no cut-off value for R2 (Esposito Vinzi et al., 2010). Hence, it is suggested that the higher the score of R2, the more robust the model. For this study, the score of $\mathrm{R} 2$ varies between 0.356 and 0.618 . The second indicator is Q2. Esposito Vinzi et al. (2010) explained that the score of Q2 for all construct must be larger than $0(\mathrm{Q} 2>0)$. In this study the Q2 for all constructs are larger than 0 . Tenenhaus GoF (Tenenhaus, Amato, \& Vinzi, 2004) suggested that GoF $=0.1$ is small, $\mathrm{GoF}=0.24$ is medium and $\mathrm{GoF}=0.36$ is large. The score of GoF is 0.573 . This GoF is considered large. Table 1 showed the score of $\mathrm{R}^{2}$ and $\mathrm{Q}^{2}$.

Table 1: Summary of Outer and Inner Model Evaluation

\begin{tabular}{|c|c|c|c|c|c|c|c|c|c|}
\hline \multirow{2}{*}{ Construct } & \multirow{2}{*}{ Code } & \multirow{2}{*}{ AVE } & \multirow{2}{*}{$\mathbf{R}^{2}$} & \multirow{2}{*}{$\mathbf{Q}^{2}$} & \multirow{2}{*}{$\begin{array}{l}\text { Composite } \\
\text { Reliability }\end{array}$} & \multicolumn{4}{|c|}{ Heterotrai-Monotrait (HTMT) } \\
\hline & & & & & & PV & TS & QoL & TL \\
\hline \multirow{4}{*}{$\begin{array}{l}\text { Perceived Value } \\
\text { (PV) }\end{array}$} & PV1 & \multirow[t]{4}{*}{0.632} & & \multirow[t]{4}{*}{0.386} & \multirow[t]{4}{*}{0.872} & & & & 0.677 \\
\hline & PV2 & & & & & & & & \\
\hline & PV3 & & & & & & & & \\
\hline & PV4 & & & & & & & & \\
\hline \multirow{3}{*}{$\begin{array}{l}\text { Tourist } \\
\text { Satisfaction (TS) }\end{array}$} & TS1 & \multirow[t]{3}{*}{0.790} & \multirow[t]{3}{*}{0.356} & \multirow[t]{3}{*}{0.54} & \multirow[t]{3}{*}{0.918} & \multirow[t]{3}{*}{0.695} & & \multirow[t]{3}{*}{0.880} & \multirow[t]{3}{*}{0.825} \\
\hline & TS2 & & & & & & & & \\
\hline & TS3 & & & & & & & & \\
\hline \multirow{7}{*}{$\begin{array}{l}\text { Quality of Life } \\
\text { (QoL) }\end{array}$} & QoL1 & \multirow[t]{7}{*}{0.516} & \multirow[t]{7}{*}{0.618} & \multirow[t]{7}{*}{0.353} & \multirow[t]{7}{*}{0.881} & \multirow[t]{7}{*}{0.727} & & & \multirow[t]{7}{*}{0.894} \\
\hline & QoL2 & & & & & & & & \\
\hline & QoL3 & & & & & & & & \\
\hline & QoL5 & & & & & & & & \\
\hline & QoL7 & & & & & & & & \\
\hline & QoL10 & & & & & & & & \\
\hline & QoL11 & & & & & & & & \\
\hline \multirow{4}{*}{$\begin{array}{l}\text { Tourist Loyalty } \\
\text { (TL) }\end{array}$} & TL1 & \multirow[t]{4}{*}{0.598} & \multirow[t]{4}{*}{0.581} & \multirow[t]{4}{*}{0.342} & \multirow[t]{4}{*}{0.854} & & & & \\
\hline & TL2 & & & & & & & & \\
\hline & TL3 & & & & & & & & \\
\hline & TL4 & & & & & & & & \\
\hline
\end{tabular}




\subsection{Hypothesis Test}

Hypothesis 1 suggests that perceived value has a significant positive effect on tourist loyalty. However, the statistical estimation showed that perceived value does not affect tourist loyalty significantly. Thus, Hypothesis 1 is not supported. While, perceived value does not affect tourist loyalty, this study indicated that tourist loyalty has significant positive effects on both quality of live $(b=0.252$; $\mathrm{t}=4.688)$ and tourist satisfaction $(\mathrm{b}=0.600 ; \mathrm{t}=13.362)$. Hence, Hypotheses 2 and 3 are supported. Hypothesis 4 contends that tourist satisfaction has a significant positive effect on quality of life. The statistical estimation found the positive significant effect of tourist satisfaction on quality of life $(b=0.609)$ as suggested by Hypothesis 4. Similar to its effect on quality of life, this study suggested that tourist satisfaction has a positive significant effect on tourist loyalty $(b=0.231 ; t=2.908)$. It means Hypothesis 5 is supported. The effect of quality of life on tourist loyalty is proposed by Hypothesis 6. The statistical calculation showed that quality of life significantly affects tourist loyalty $(b=0.505$; $\mathrm{t}=6.965)$. This finding means Hypothesis 6 is supported.

The mediating effects were proposed by Hypotheses 7 and 8. Hypothesis 7 suggested that quality of life significantly mediated the effect of perceived value on tourist loyalty. The mediating test analysis indicated that quality of life significantly mediated the effect of perceived value on tourist loyalty $(b=0.126 ; 4.112)$ as suggested by Hypothesis 7. Similar to quality of life, the mediating test analysis found that tourist satisfaction mediated the effect of perceived value on tourist loyalty $(b=0.139 ; t=2.729)$. It means Hypothesis 8 is supported. Table 2. Summarizes the results of causality relationships.

Hypotheses 1 to 8 proposed the relationships among constructs; Hypotheses 9 to 11 test the multi-group differences. Hypothesis 9 proposed that there are differences among demographic dimensions, namely, gender, marital status and origin related to the effect of perceived value on tourist loyalty. The multi-group analysis showed that there is not difference among gender, marital status and origin related to the effect of perceived value on tourist loyalty. This finding means Hypotheses 9a, 9b and 9c are not supported. Hypothesis 10 proposed that demographics moderated the effect of tourist satisfaction on tourist loyalty. However, multi-group analysis found that there is no different among gender, marital status and origin with respect to the effect of tourist satisfaction on tourist loyalty. This result means Hypotheses $10 \mathrm{a}, 10 \mathrm{~b}$ and $10 \mathrm{c}$ are not supported. The moderating effect of demographics with respect on the effect of quality of life on tourist loyalty was proposed by Hypothesis 11. The multi-group analysis showed that there is no different among gender, marital status and gender relate to the effect of quality of life on tourist loyalty. Hence, Hypotheses $11 \mathrm{a}, 11 \mathrm{~b}$ and $11 \mathrm{c}$ are not supported. Table 3 summarizes the results of multi-group analysis.

\subsection{Discussion}

Three research objectives are addressed in this study. The first objective is to determine the relationship among perceived value, tourist satisfaction, quality of life, and tourist loyalty in Indonesia adventure tourism. The second objective is to determine the indirect effects of perceived value of tourist loyalty through tourist satisfaction and quality of life, and the third objective is to examine the moderating effects of demographics (i.e., gender, marital status, and tourist origin). The following section discusses the finding of this study.

While perceived value has been recognized widely in the area of marketing and tourism studies as the determinant of customer loyalty, this study did not find the significant effect of perceived value of tourist loyalty. This study found that

Table 2: Summary of Causality Analysis

\begin{tabular}{|l|l|c|c|c|}
\hline Hypothesis & Path & Coefficient & t-statistic & Mark \\
\hline H1 & PV $\rightarrow$ TL & 0.099 & 1.543 & Not Supported \\
\hline H2 & PV $\rightarrow$ QoL & 0.252 & $4.688^{*}$ & Supported \\
\hline H3 & PV $\rightarrow$ TS & 0.600 & $13.362^{* *}$ & Supported \\
\hline H4 & TS $\rightarrow$ QoL & 0.609 & $11.595^{* *}$ & Supported \\
\hline H5 & TS $\rightarrow$ TL & 0.231 & 2.908 & Supported \\
\hline H6 & QoL $\rightarrow$ TL & 0.505 & $6.965^{\star *}$ & Supported \\
\hline H7 & PV $\rightarrow$ QoL $\rightarrow$ TL & 0.126 & $4.112^{*}$ & Supported \\
\hline H8 & PV $\rightarrow$ TS $\rightarrow$ TL & 0.139 & 2.729 & Supported \\
\hline
\end{tabular}


Table 3: Multi Group Analysis

\begin{tabular}{|c|c|c|c|c|c|}
\hline Hypothesis & Demography & Path & & & p-val \\
\hline \multirow[t]{2}{*}{$\mathrm{H} 9 \mathrm{a}$} & \multirow[t]{2}{*}{ Gender } & \multirow[t]{2}{*}{$\mathrm{PV} \rightarrow \mathrm{TL}$} & Male & Female & \multirow[t]{2}{*}{$0.323 \mathrm{~ns}$} \\
\hline & & & $0.098 \mathrm{~ns}$ & $0.099 n s$ & \\
\hline \multirow[t]{2}{*}{$\mathrm{H} 9 \mathrm{~b}$} & \multirow[t]{2}{*}{ Marital Status } & \multirow[t]{2}{*}{$\mathrm{PV} \rightarrow \mathrm{TL}$} & Single & Married & \multirow[t]{2}{*}{$0.967 \mathrm{~ns}$} \\
\hline & & & $0.103 \mathrm{~ns}$ & $0.105 \mathrm{~ns}$ & \\
\hline \multirow[t]{2}{*}{$\mathrm{H} 9 \mathrm{c}$} & \multirow[t]{2}{*}{ Origin } & \multirow[t]{2}{*}{$\mathrm{PV} \rightarrow \mathrm{TL}$} & Local & Non-Local & \multirow[t]{2}{*}{$0.089 \mathrm{~ns}$} \\
\hline & & & $0.102 \mathrm{~ns}$ & $0.100 \mathrm{~ns}$ & \\
\hline \multirow[t]{2}{*}{$\mathrm{H} 10 \mathrm{a}$} & \multirow[t]{2}{*}{ Gender } & \multirow[t]{2}{*}{$\mathrm{TS} \rightarrow \mathrm{TL}$} & Male & Female & \multirow[t]{2}{*}{$0.990 \mathrm{~ns}$} \\
\hline & & & 0.235 & 0.237 & \\
\hline \multirow[t]{2}{*}{$\mathrm{H} 10 \mathrm{~b}$} & \multirow[t]{2}{*}{ Marital Status } & \multirow[t]{2}{*}{$\mathrm{TS} \rightarrow \mathrm{TL}$} & Single & Married & \multirow[t]{2}{*}{$0.833 \mathrm{~ns}$} \\
\hline & & & 0.232 & 0.231 & \\
\hline \multirow[t]{2}{*}{$\mathrm{H} 10 \mathrm{c}$} & \multirow[t]{2}{*}{ Origin } & \multirow[t]{2}{*}{$\mathrm{TS} \rightarrow \mathrm{TL}$} & Local & Non-Local & \multirow[t]{2}{*}{$0.634 n s$} \\
\hline & & & 0.239 & 0.234 & \\
\hline \multirow[t]{2}{*}{$\mathrm{H} 11 \mathrm{a}$} & \multirow[t]{2}{*}{ Gender } & \multirow[t]{2}{*}{ QoL $\rightarrow$ TL } & Male & Female & \multirow[t]{2}{*}{$0.278 \mathrm{~ns}$} \\
\hline & & & $0.504^{*}$ & $0.501^{*}$ & \\
\hline \multirow[t]{2}{*}{$\mathrm{H} 11 \mathrm{~b}$} & \multirow[t]{2}{*}{ Marital Status } & \multirow[t]{2}{*}{ QoL $\rightarrow$ TL } & Single & Married & \multirow[t]{2}{*}{$0.823 \mathrm{~ns}$} \\
\hline & & & $0.502^{*}$ & $0.501^{*}$ & \\
\hline \multirow[t]{2}{*}{$\mathrm{H} 11 \mathrm{c}$} & \multirow[t]{2}{*}{ Origin } & \multirow[t]{2}{*}{ QoL $\rightarrow$ TL } & Local & Non-Local & \multirow[t]{2}{*}{$0.078 \mathrm{~ns}$} \\
\hline & & & $0.496^{*}$ & $0.501^{*}$ & \\
\hline
\end{tabular}

*sig p<0.01; ns: not-significant__

perceived value has a significant positive effect on tourist quality of life. It means, the happiness of tourists will increase when they perceived good value of tourism destination visited. Theoretically, this finding supports previous studies by Berutu et al. (2020); Ma et al. (2018) who suggested the important of tourist perceived value on quality of life. Similar to its effect on quality of life, this study showed the effect of perceived value on tourist satisfaction. This significant effect implies that the higher the perceived value, the higher the tourist satisfaction. It validates previous studies (Channoi et al., 2018; Hapsari et al., 2017; Hussein \& Hapsari, 2020).

Similar to perceived value, this study revealed the important role of tourist satisfaction on quality of life. This finding validates the study by Berutu et al. (2020) and Chen et al. (2016) who suggested the essential role of satisfaction in boosting tourist happiness. Apart from its significant effect on quality of life, this study found the significant effect of tourist satisfaction on tourist loyalty. It means the higher the tourist satisfaction, the higher the tourist loyalty. This finding validated previous research (Hapsari, 2018; Le \& Le, 2020; Nguyen, 2020; Wu et al., 2014) that showed the significant effect of tourist satisfaction on loyalty.

While only few studies have discussed the importance of quality of life, this study indicated the effect of quality of life on tourist loyalty. This finding stated that the higher the quality of life on visiting the tourist site, the higher the tourist loyalty. Theoretically, the findings supported the study by Hernandez-Mogollon et al. (2020) suggesting the role of quality of life in sustaining tourist loyalty.

\section{Conclusions}

As this study revealed the effect of perceived value on quality of life, and it also showed that quality of life has a significant positive effect on tourist loyalty; this study suggested that quality of life mediates the effect of perceived value on tourist loyalty. Because of no direct effect of perceived value on tourist loyalty was found, the mediating effect was considered a full mediation. Similar to quality of life, this study showed that tourist satisfaction mediates the effect of perceived value on tourist loyalty. The mediating effect is recognized as full mediation.

Three demographics variables, namely, gender, marital status, and tourist origin were tested as moderating variable in moderating the effect of perceived value, tourist satisfaction and quality of life on tourist loyalty. However, the multi-group analysis did not find these moderating variables. Thus, it can be concluded that there is no difference among demographics 
variables with respect to the effect of perceived value, tourist satisfaction and quality of life on tourist loyalty.

This study provides both theoretical and practical contributions. From a theoretical standpoint, this study offers a model explaining the interrelationships among perceived value, tourist satisfaction, quality of life, and tourist loyalty in the context of Indonesia adventure tourism destination. Moreover, this study suggested that the value perceived by adventurer will not directly affect the loyalty. It must be mediated by mediating variables. This study indicated that both tourist satisfaction and quality of life mediated the effect of perceived value of tourist loyalty. From a practical standpoint, this study suggests to tourism adventure management to enhance the value offered as the visit value is important to enhance satisfaction and quality of life, which lastly generate loyalty. Enhancing perceived value might be conducive to providing more experience and facilities to the tourist as well as reducing the cost of visit.

\section{References}

Adventure Travel Trade Association. (2015). Adventure tourism development index 2015. Seattle, WA: Adventure Travel Trade Association.

Baron, R. M., \& Kenny, D. A. (1986). The moderator-mediator variable distinction in social psychological research: conceptual, strategic, and statistical considerations. Journal of Personality and Social Psychology, 51(6). https://doi.org/10.1037//00223514.51.6.1173

Berutu, M. B., Rohman, F., \& Hussein, A. S. (2020). The role of quality of life as a mediation effect of perceived value and tourist satisfaction on behavioral intention. Jurnal Aplikasi Manajemen, [In Press].

Bialeschki, M. D., \& Henderson, K. (2000). Gender issues and recreation management. In: M. Allison \& I. Schneider (Eds.), Diversity and the recreation professions: Organizational perspectives (pp. 73-97). State College, PA: Venture Publishing Inc

Bosnjak, M., Sirgy, M. J., Hellriegel, S., \& Maurer, O. (2011). Post visit destination loyalty judgments: Developing and testing a comprehensive congruity model. Journal of Travel Research, 50(5), 496-508

Boyes, M. (2013). Outdoor adventure and successful ageing. Ageing and Society, 33(4), 644-665

Brymer, E., \& Gray, T. (2010). Developing an intimate "relationship" with nature through extreme sports participation. Leisure/Loisir, 34(4), 361-374

Brymer, E., Downey, G., \& Gray, T. (2009). Extreme sports as a precursor to environmental sustainability. Journal of Sport \& Tourism, 14(2-3), 193-204

Buckley, R. (2010). Adventure tourism management. Oxford, UK: Butterworth-Heinemann.
Calderwood, L. U., \& Soshkin, M. (2019). The Travel \& Tourism Competitiveness Report 2019: Travel and Tourism at a Tipping Point. Cologny, Switzerland: World Economic Forum.

Carneiro, M. J., \& Eusébio, C. (2012). Segmentation of the tourism market using the impact of tourism on quality of life. Tourism \& Management Studies, 7, 91-100.

Cater, C. (2006). Playing with risk? Participant perceptions of risk and management implications in adventure tourism. Tourism Management, 27(2), 317-325

Chandel, J. K., \& Bansal, S. P. (2014). Understanding the relationships of value, satisfaction and behavioural intentions among adventure tourists. International Journal of Leisure and Tourism Marketing, 4(2), 156-171.

Chandel, J. K., Bansal, S. P., \& Gattoufi, S. (2018). Examining the Relationships among Antecedents of Behavioural Intentions in Adventure Sports Context. Polish Journal of Sport and Tourism, 25(1), 39-47.

Channoi, R., Clemes, M. D., \& Dean, D. L. (2018). A comprehensive hierarchical model of beach resort hotel stays. Journal of Hospitality and Tourism Management, 37, 107-116. https://doi. org/https://doi.org/10.1016/j.jhtm.2017.10.011

Chen, C. F., \& Chen, F. S. (2010). Experience quality, perceived value, satisfaction and behavioral intentions for heritage tourists. Tourism Management, 31(1), 29-35.

Chen, Y., Fu, X., \& Lehto, X. Y. (2016a). Chinese Tourist Vacation Satisfaction and Subjective Well-being. Applied Research in Quality of Life, 11(1), 49-64. https://doi.org/10.1007/s11482014-9354-y

Chen, Y., Fu, X., \& Lehto, X. Y. (2016b). Chinese Tourist Vacation Satisfaction and Subjective Well-being. Applied Research in Quality of Life, 11, 49-64. https://doi.org/10.1007/s11482-0149354-y

Cohen, S. A., Prayag, G., \& Moital, M. (2014). Consumer behaviour in tourism: Concepts, influences and opportunities. Current issues in Tourism, 17(10), 872-909.

Cole, D. (2004). Impacts of hiking and camping on soils and vegetation: A review. In: R. Buckley (Ed.), Environmental impacts of ecotourism (pp. 41-60). Wallingford, UK: CABI.

Correia, A., Moital, M., Oliveira, N., \& Costa, C. F. (2009). Multidimensional segmentation of gastronomic tourists based on motivation and satisfaction. International Journal of Tourism Policy, 2(1/2), 58-71.

El-Adly, M. I. (2019). Modelling the relationship between hotel perceived value, customer satisfaction, and customer loyalty. Journal of Retailing and Consumer Services, 50, 322-332. https://doi.org/https://doi.org/10.1016/j.jretconser.2018.07.007

Esposito Vinzi, V., Chin, W., Henseler, J., \& Wang, H. (Eds.). (2010). How To Write Up and Report PLS Analyses. In: Handbook of Partial Least Squares. Hiedelberg, Germany: Springer Berlin Heidelberg.

Eusobio, C., Carneiro, M. J., Kastenholz, E., \& Alvelos, H. (2016). The impact of social tourism for seniors on the economic 
development of tourism destinations. European Journal of Tourism Research, 12, 5-24.

Giddy, J. K., \& Webb, N. L. (2018). The influence of the environment on adventure tourism: from motivations to experiences. Current Issues in Tourism, 21(18), 2124-2138.

Hair, J. F., Hult, G. T. M., Ringle, C. M., \& Sarstedt, M. (2014). A primer of partial least squares structural equation modelling (PLS-SEM). Thousand Oaks, CA: Sage Publications.

Hapsari, R. (2018). Creating educational theme park visitor loyalty: the role of experience-based satisfaction, image and value. Tourism and Hospitality Management, 24(2), 274-359.

Hapsari, R., Clemes, M., \& Dean, D. (2017). The impact of service quality, customer engagement and selected marketing constructs on airline passenger loyalty. International Journal of Quality and Service Sciences, 9(1), 21-40. https://doi. org/10.1108/IJQSS-07-2016-0048

Hernandez-Mogollon, J. M., Di-Clemente, E., \& Campon-Cerro, A. M. (2020). Culinary travel experiences, quality of life and loyalty. Spanish Journal of Marketing-ESIC. [In Press] https:// doi.org/10.1108/SJME-11-2019-0094

Homburg, C., Koschate, N. and Hoyer, W.D. (2005) 'Do satisfied customers really pay more? A study of the relationship between customer satisfaction and willingness to pay'. Journal of Marketing, 69(2), 84-96.

Hudson, S. (2012). Sport and adventure tourism. London, UK: Routledge.

Hussein, A. S, Hapsari, R. D. V., \& Yulianti, I. (2018). Experience quality and hotel boutique customer loyalty: Mediating role of hotel image and perceived value. Journal of Quality Assurance in Hospitality \& Tourism, 19(4), 442-459. https://doi.org/10.10 80/1528008X.2018.1429981

Hussein, A. S., \& Hapsari, R. (2020). Heritage experiential quality and behavioral intention: lessons from Indonesian heritage hotel consumers. Journal Heritage Tourism. [In Press] https:// doi.org/10.1080/1743873X.2020.1792474

Ismail, M. N. I., Hanafiah, M. H., Aminuddin, N., \& Mustafa, N. (2016). Community-based homestay service quality, visitor satisfaction, and behavioral intention. Procedia-Social and Behavioral Sciences, 222, 398-405.

Jin, N., Lee, S., \& Lee, H. (2015). The effect of experience quality on perceived value, satisfaction, image and behavioral intention of water park patrons: New versus repeat visitors. International Journal of Tourism Research, 17(1), 82-95.

Kim, Y. K., \& Lee, H. R. (2011). Customer satisfaction using low cost carriers. Tourism Management, 32(2), 235-243.

Le, H. B. H., \& Le, T. B. (2020). Impact of destination image and satisfaction on tourist loyalty: Mountain destinations in Thanh Hoa Province, Vietnam. Journal of Asian Finance, Economics and Business, 7(4), 185-195. https://doi.org/doi:10.13106/ jafeb.2020.vol7.no4.185

Leung, Y. F., \& Marion, J. L. (2004). Managing impacts of camping. In: R. Buckley (Ed.), Environmental impacts of ecotourism (pp. 245-250). Wallingford, UK: CABI.
Lucrezi, S., Saayman, M., \& van der Merwe, P. (2013). Managing diving impacts on reef ecosystems: Analysis of putative influences of motivations, marine life preferences and experience on divers' environmental perceptions. Ocean \& Coastal Management, 76, 52-63

Ma, L., Zhang, X., Ding, X., \& Wang, G. (2018). Bike sharing and users' subjective well-being: An empirical study in China. Transportation Research Part A, 118, 14-24. https://doi. org/10.1016/j.tra.2018.08.040

Li, M.-L. (2011). Impact of Marketing Strategy, Customer Perceived Value, Customer Satisfaction, Trust, and Commitment on Customer Loyalty. [Lynn University, Boca Raton, Florida]. https://search.proquest.com/openview/36489cda9dcb541c30d $3547 \mathrm{e} 7130675 \mathrm{a} / 1$ ?pq-origsite $=\mathrm{gscholar} \& \mathrm{cbl}=18750 \&$ diss $=\mathrm{y}$

Neal, J. D., Uysal, M., \& Sirgy, M. J. (2007). The effect of tourism services on travelers' quality of life. Journal of Travel Research, 46(2), 154-163.

Nguyen, X. T. (2020). Factors that influence the intentions to revisit Korea of Vietnamese tourists. Journal of Asian Finance, Economics and Business, 7(4), 247-258. https://doi. org/10.13106/jafeb.2020.vol7.no4.247

Oliver, R. (1997). Satisfaction: A behavioral perspective on the consumer. New York, NY: McGraw Hill.

Oppermann, M. (2000). Tourism destination loyalty. Journal of Travel Research, 39, 78-84.

Pandža Bajs, I. (2015). Tourist perceived value, relationship to satisfaction, and behavioral intentions: The example of the Croatian tourist destination Dubrovnik. Journal of Travel Research, 54(1), 122-134.

Patterson, I., \& Pan, R. (2007). The motivations of baby boomers to participate in adventure tourism and the implications for adventure tour providers. Annals of Leisure Research, 10(1), 26-53

Pomfret, G., \& Bramwell, B. (2016). The characteristics and motivational decisions of outdoor adventure tourists: A review and analysis. Current Issues in Tourism, 19(14), 1447-1478.

Prayag, G., Hosany, S., \& Odeh, K. (2013). The role of tourists' emotional experiences and satisfaction in understanding behavioral intentions. Journal of Destination Marketing \& Management, 2(2), 118-127.

Rasoolimanesh, S. M., Dahlan, N., \& Jaafar, M. (2016). Tourists' perceived value and satisfaction in a community-based homestay in the Lenggong Valley World Heritage Site. Journal of Hospitality and Tourism Management, 72-81. https://doi.org/ https://doi.org/10.1016/j.jhtm.2016.01.005

Schultz, P. W. (2000). New environmental theories: Empathizing with nature: The effects of perspective taking on concern for environmental issues. Journal of Social Issues, 56(3), 391-406.

Sweeney, J. C., \& Soutar, G. N. (2001). Consumer perceived value: The development of a multiple item scale. Journal of retailing, 77(2), 203-220. 
Sweeney, J., \& Soutar, G. N. (2001). Consumer perceived value: The development of a multiple item scale. Journal of Retailing, 77(2), 203-220. https://doi.org/10.1016/S0022-4359(01)00041-0

Tenenhaus, M., Amato, S., \& Vinzi, V. E. (2004). A global goodnessof-fit index for PLS.

Tran, V. D. (2020). Assessing the effects of service quality, experience value, relationship quality on behavioral intentions. Journal of Asian Finance, Economics and Business, 7(3), 167-175. https://doi.org/10.13106/jafeb.2020.vol7.no3.167

Ventegodt, S., Merrick, J., \& Andersen, N. J. (2003). Quality of Life Theory I. The IQOL Theory: An Integrative Theory of the Global Quality of Life Concept. The Scientific World Journal, 3, 1030-1040.
Williams, P., \& Soutar, G. N. (2009). Value, satisfaction and behavioral intentions in an adventure tourism context. Annals of Tourism Research, 36(3), 413-438.

Wu, H.-C., Li, M.-Y., \& Li, T. (2014). A Study of Experiential Quality, Experiential Value, Experiential Satisfaction, Theme Park Image, and Revisit Intention. Journal of Hospitality \& Tourism Research, 42(1), 26-73. https://doi. org/10.1177/1096348014563396

Zabkar, V., Brenčič, M. M., \& Dmitrović, T. (2010). Modelling perceived quality, visitor satisfaction and behavioural intentions at the destination level. Tourism Management, 31(4), 537-546. 